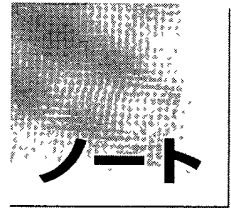

論文受付

2003年 5 月30日

論文受理

2003年 8 月15日

Code No. 750

\section{陽子線治療におけるCT-治療共通ベッドを使用した 患者位置決めシステムの概要と検討}

\author{
横濱則也 - 鍵谷 豪 - 丸山市郎 - 西島昭彦1) - 山本和高 \\ 若狭湾工ネルギ一研究センター粒子線医療研究室 \\ 1 ) 福井医科大学医学部附属病院放射線部
}

\section{緒 言}

高エネルギーX線治療施設では，通常，患者体表面 におけるマーキングとリニアックグラフィを用いて位 置照合が行われている．陽子線治療においては，病巣 への線量集中性が高いために，照射ごとの位置再現性 が重要な問題となる。陽子線治療施設における照射時 の位置照合は，X-TV(X-ray TeleVision)を使用して 2 方向からX線画像を取得し, 治療計画作成時のCT (computed tomography) 画像から再構成した, DRR (digitally reconstructed radiograph)を基にして，病巣 近傍の骨の位置・形態や臓器に埋め込まれたマーカー を一致させることによって行っている．近年，DR (digital radiography)の連続撮影技術とデジタル差分技 術を駆使した位置照合も実施されるようになったが, 二次元平面だけの照合に留まっており，患者の回転な どへの対応に時間がかかっている．また，治療計画に 使用されるCTやDR, 撮影用ベッドは患者照射室のも
のとは別で，両者間に照射位置のずれを生じる可能性 も否定できない.

若狭湾エネルギー研究センターでは，患者位置を， 高精度にかつ簡便に照合を実現できることを目指し て, 陽子線治療施設としては初めて, 陽子線照射装置 に隣接してCTを設置し，CT撮影ベッドと陽子線治療 用ベッドを共通化することにより，照射ごとにCTを 撮影して病巣の位置を正確に把握し, 患者を動かすこ となく陽子線照射位置へ移動することが可能なシステ ムを導入した。

これらの機器の概要を紹介し, 機械的な位置再現性 について報告する。

\section{1. 機器の僟構と位㯰決め手順}

\section{1-1 共通ベッドの機構}

Fig. 1において，陽子線照射装置，CT，共通ベッド の位置関係を $\mathrm{a}, \mathrm{CT} に よ る$ 位㯰決めをb(1)，共通ベッ

\title{
New Patient Positioning System for Proton Therapy Combined with CT with a Common Treatment Couch
}

\section{NORIYA YOKOHAMA, GO KAGIYA, ICHIRO MARUYAMA, AKIHIKO NISHIJIMA, 1) and KAZUTAKA YAMAMOTO}

The Wakasa-Wan Energy Research Center Medical Division

1 ) Department of Radıology, Fukui Medical University Hospital

Received May 30, 2003; Revision accepted Aug. 15, 2003; Code No. 750

\section{T2. Shmorimy}

Exact reproducibility of patient positioning is a critical issue for proton therapy because of the sharp dose distribution. We constructed the first proton therapy system with a common couch for both CT and proton irradiation. In this paper, we report a brief overview of the instruments and the accuracy of mechanical positioning reproducibility.

\section{Key words: Proton therapy, Computed tomography (CT), Common treatment couch, Patient positioning}



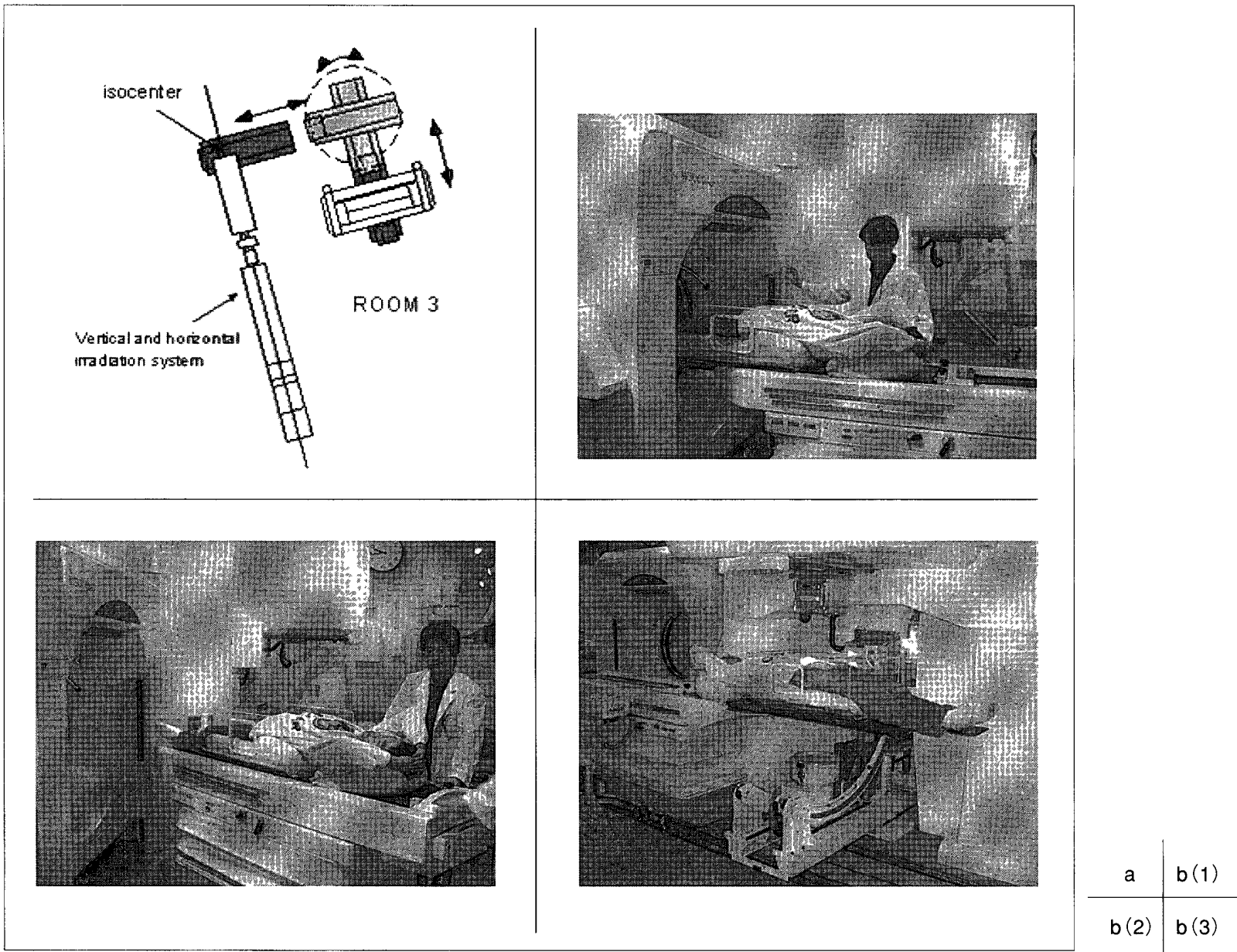

Fig. 1 (a) Appearance and mechanism figure of CT-Treatment common couch, that looked down on from the ceiling.

b(1) Patient positioning using CT Simulator.

b (2) Move common couch to irradiation position.

b (3) Fix the position of irradiation.

ドの移動を $\mathrm{b}(2)$, 照射位置への設置状態を $\mathrm{b}(3)$ に示 す。こうしたCTとリニアック共通ベッド機構は報告 されているが1 3)，当センターでは，CTは陽子線照射 装置に隣接して床面に固定されており，CTガントリ は移動しない。共通ベッドはCT撮影後, 90度もしく は270度回転し，その後レール上を直進して，照射位 置へ移動できるようになっている。レールには一定の 位置にベッドを固定できる機構が設けられており，そ こに共通ベッドを固定しCTシミュレータが指定する ベッドの移動量を反映させると, CT画像上で決定し た病巣の中心を，陽子線治療照射中心(アイソセンタ) に一致させることができる．CT位置決め用レーザマ 一カの 3 軸は, アイソセン夕を示すレーザマーカの 3 軸に高精度に対応するよう設定されている，共通ベッ ドの材質はカーボンファイバー製で，患者固定具等を 支持できるように開発した，木製掞よび樹脂製の固定 具支持台を設置できる(Fig. 2)。また，垂直，水平方 向以外から陽子線を照射できるように, 回転可能な患 者固定装置を交換装着することもできる。
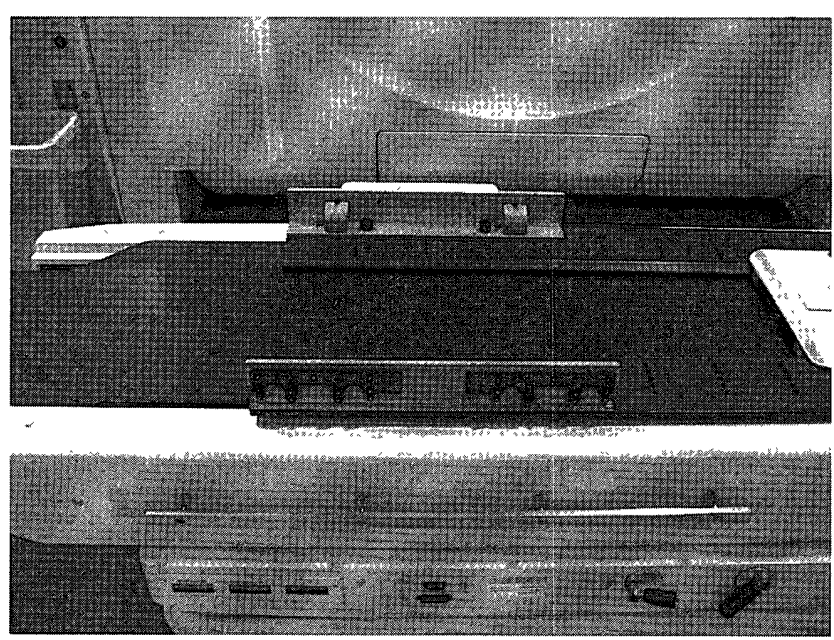

Fig. 2 Patient fixed implement's fulcrums made of wood and resin.

\section{1-2 治療計画}

陽子線治療時と同じ体位にて, 水硬化性固定具 (ア ルケア，千代田テクノル社製）用いて，患者ごとに 固定具を作成する。さらに，熱可塑性樹脂シート（エ 
スフォーム，システムエンジニアリング社製，以下固 定シェル)を，患者体表の形に合わせて整形して固定す る.この状態でCT (CT-W3000AD，日立メディコ社製) にて関心臓器周辺の撮影を行い, 治療計画装置(日立三 次元陽子線治療計画システム，日立製作所製)へCT画 像デー夕を, DICOM(Digital Imaging and Communications in Medicine) プロトコルにて転送する．治療計画 装置にてプラン作成後, 照射パラメータを治療管理シ ステム (日立製作所製)，DRRおよびアイソセンタとそ の周囲のCT画像を, DICOMサーバへ登録する。

\section{1-3 患者位置決め手順}

共通ベッドに患者固定具と固定シェルを用いて患者 を固定する，患者位置決めのために，CTにて病巣周 囲の撮影を行い, CTシミュレータ (CT Sim, 日立メデ イコ社製)へ画像をDICOMプロトコルにて転送する.

DICOM viewerにて，治療計画時に設定した病巣中心 と, その周囲のCT画像を参照しながら, 医師が, CT シミュレータに表示された位置決め用CT画像上での 病巣中心を決定する. CTシミュレータは, CT画像中 心から決定した病巣中心への移動量を，3軸方向に算 出し, CT位置決めレーザマーカ $(\mathrm{CT}$ ポート)へそのデ 一タを転送する. 固定シェルに投光されたレーザに合 わせてマーキングを行う。その後，共通ベッドを陽子 線照射位置まで一定量移動し，陽子線照射位置のアイ ソセンタを示すレーザマーカと, シェルに記録された マーキングとの位置関係を確認する。さらにDR （1000DR，日立メディコ社製）でX線撮影し，骨形状 を，前回のX線画像と比較して照射位置を確認し，そ の後陽子線照射を行う.

\section{2. 方 法}

\section{2-1 位置再現性の検証方法}

検証ツールとして，Fig. 3に示す．X，Y，Zの3 軸 にスチール製のピアノ線 $(\phi 0.5 \mathrm{~mm}$, 長さ $200 \mathrm{~mm})$ と, その 3軸中心に $\phi 0.5 \mathrm{~mm}$ の鉄球を埋め込んた，一辺が $200 \mathrm{~mm}$ の立方体形状である，アクリル製キューブフ アントムを作成した。

\section{2-1-1 CT画像, CTポート間におけるレーザを基準} とした検証

検証ツールを共通ベッドに設置し，73kg均等に荷重 した上で, CTポートにおけるレーザマーカと検証ツ 一ル内ピアノ線の 3 軸交点を一致させる. CT撮影して から，CT画像上で，グリッド機能を用いて， CT画像 中心と 3 軸交点とのずれを計測した。

2-1-2ＣT，照射位置間における，レーザを基準とし た検証

共通ベッドにおのおの $38.5 \mathrm{~kg}, 73.5 \mathrm{~kg}, 109.9 \mathrm{~kg}$

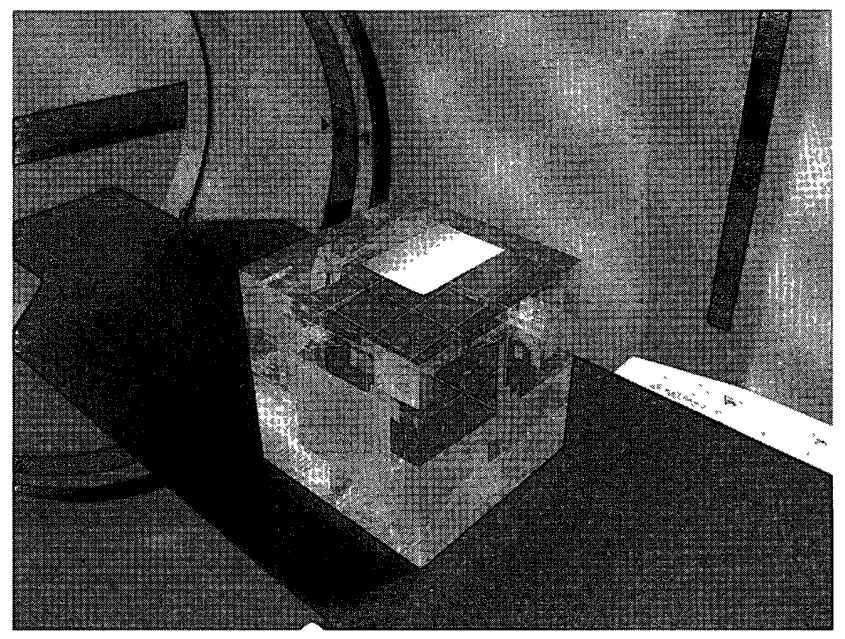

Fig. 3 Appearance of verification tool used for gap verification of positioning equipment.

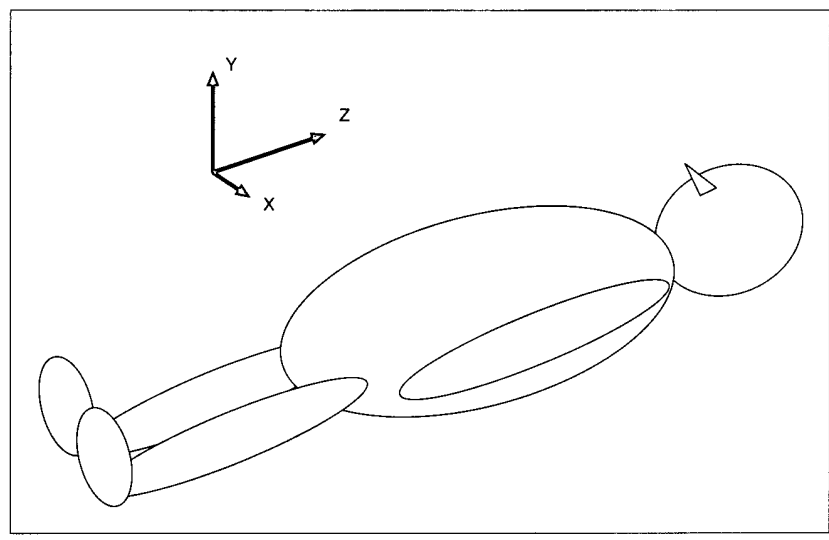

Fig. 4 Spatial coordinates of a patient.

を，均等に荷重した状態で，CTポートでのレーザマ 一力位置と，陽子線照射位置におけるレーザマーカの 位置との再現性を，アクリル製キューブファントムの 上面および側面の3面に方眼紙を貼ったものを用いて 測定した。それぞれ，頭および足の両方向挿入した場 合において，測定時期を 2 回に分けて，それぞれ3 回，計 6 回測定を行った.さらに，67kgの健常ボラン ティアを実際に共通ベッドに載せた状態でも，同様に 測定した。.Fig. 4に患者に対する座表系を示す。

2-1-3 CT，照射位置間における，DRを基準とした 検証

$73 \mathrm{~kg}$ 均等に荷重した上で，CT撮影した後，CTシミ ュレータへCT画像データを転送し，CTシミュレータ 上で検証ツール内ピアノ線の 3 軸交点中心をアイソセ ンタとした. その後, 陽子線照射位置へ共通ベッドを 移動して固定後, CTシミュレータで設定した移動量 を反映させた．DRにて検証ツールの十字線中心と陽 子線照射位置でのアイソセンタを示す, I.I. (イメージ インテンシファイア)に設置された十字ピアノ線中心 
とのずれを測定した．陽子線照射位置への挿入方向 は，レーザによる検証と同様である。CTの撮影条件 は, $120 \mathrm{kV}, 200 \mathrm{~mA}, 1 \mathrm{sec} / \mathrm{scan}, 1 \mathrm{~mm}$ thickness, $0.5 \mathrm{~mm}$ gap, FOV $350 \mathrm{~mm}$ で, コンベンショナルスキャ ンを使用した.

\section{2-2 スキャン方式によるZ軸方向の検証}

スキャン方式の違いによって, 画像再構成した際の 体軸方向位置を検証するため，コンベンショナルスキ ヤンとヘリカルスキャン(ヘリカルピッチは1.0, 再構 成パラメータは，コンベンショナルスキャンに準じ る）を実施した，手順として，いずれのスキャン方式 も，スカウト画像上で，検証ッール3 軸交点の位置を 原点として設定した。 その後アキシャル画像を再構成 し，CTが示す体軸方向の位置情報を測定した。

\section{3. 結 果}

\section{3-1 CT画像，CTポート間におけるレーザを基準と した検証}

CTポートとCT撮影中心とのずれは，X軸，Y 軸方 向では，CT画像上ピクセル換算で $0.65 \mathrm{~mm}$ 以下，Z軸 方向はエンコーダカウント換算で $0.5 \mathrm{~mm}$ 以下となり, ずれは，測定限界以下であった。

\section{3-2ＣT，照射位置間における，レーザを基準とした 検証}

Table 1 に頭方向から挿入した場合，Table 2 に足方 向から挿入した場合の，ずれの平均と標準偏差を示 す。いずれの条件においても，CT，照射位置間のず れは $1 \mathrm{~mm}$ 以下であり，共通ベッドへの荷重 $38.5 \mathrm{~kg}$, $109.9 \mathrm{~kg}$ と変化させても, 同様の結果が得られた。 $67 \mathrm{~kg}$ の健常ボランティアに扔いても Table 3に示すよ うに同様であった。

\section{3-3ＣT，照射位置間における，DRを基準とした検証} 検証ツール内ピアノ線の3軸交点中心と，I.I.表面の 中心に設置したピアノ線中心との，DR画像における ずれは，Table 4に示すように $1 \mathrm{~mm}$ 以下であった。

\section{3-4 スキャン方式によるZ軸方向の検証}

コンベンショナルスキャン時に㧍ける，画像上のZ 軸のずれは確認できないが，ヘリカルスキャンにおい

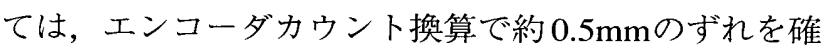
認した

\section{4. 考 察}

陽子線がん治療では，陽子線が形成するbragg peak を, ridge filter等で拡大したSOBP(spead out bragg
Table 1 Amount of gaps of the CT laser and the irradiation position laser in each load (Head first).

\begin{tabular}{cccc}
\hline Weight $[\mathrm{kg}]$ & $\mathrm{X}$ axis $[\mathrm{mm}]$ & $\mathrm{Y}$ axis $[\mathrm{mm}]$ & $\mathrm{Z}$ axis $[\mathrm{mm}]$ \\
\hline 38.6 & $0.5(0.2)$ & $-0.2(0.0)$ & $0.0(0.0)$ \\
73.5 & $0.4(0.2)$ & $0.5(0.3)$ & $0.5(0.2)$ \\
109.9 & $0.4(0.1)$ & $0.7(0.0)$ & $0.0(0.0)$ \\
\hline
\end{tabular}

Table 2 Amount of gaps of the CT laser and the irradiation position laser in each load (Foot first).

\begin{tabular}{cccc}
\hline \hline Weight $[\mathrm{kg}]$ & $\mathrm{X}$ axis $[\mathrm{mm}]$ & $\mathrm{Y}$ axis $[\mathrm{mm}]$ & $\mathrm{Z}$ axis $[\mathrm{mm}]$ \\
\hline 38.6 & $0.8(0.1)$ & $-0.6(0.1)$ & $-0.9(0.2)$ \\
73.5 & $0.7(0.2)$ & $-0.4(0.3)$ & $-0.6(0.1)$ \\
109.9 & $0.7(0.2)$ & $0.0(0.1)$ & $-0.6(0.2)$ \\
\hline
\end{tabular}

Table 3 Amount of gaps of the CT laser and the irradiation position laser in a $67 \mathrm{~kg}$ human body.

\begin{tabular}{lccc}
\hline \hline Direction & $X$ axis $[\mathrm{mm}]$ & $Y$ axis $[\mathrm{mm}]$ & $Z$ axis $[\mathrm{mm}]$ \\
\hline Head First & $0.3(0.2)$ & $0.9(0.1)$ & $0.6(0.0)$ \\
Foot First & $0.6(0.2)$ & $0.1(0.1)$ & $-0.2(0.3)$ \\
\hline
\end{tabular}

Table 4 Amount of gaps of the CT laser and the irradiation position cross wire in DR with a $73.5 \mathrm{~kg}$ weight (mean \& SD).

\begin{tabular}{lccc}
\hline \hline Direction & $X$ axis $[\mathrm{mm}]$ & $\mathrm{Y}$ axis $[\mathrm{mm}]$ & $\mathrm{Z}$ axis $[\mathrm{mm}]$ \\
\hline Head First & $-0.4(0.3)$ & $-0.8(0.1)$ & $-0.3(0.2)$ \\
Foot First & $0.7(0.3)$ & $-0.3(0.2)$ & $0.0(0.0)$ \\
\hline
\end{tabular}

peak）を利用している。 $180 \mathrm{MeV}$ 陽子線のdistal fall-off は約 $3 \mathrm{~mm}(80 \% \rightarrow 20 \%)$ と, 照射野辺縁は極めてシャ ープになるので, 患者位置再現性は重要な要素であ る.

当センターでは，粒子線治療では初めてCT-治療共 通ベッドを使用して，治療計画作成用データの取得と 照射ごとの位置決めに利用している。これにより従来 のDRを用いる方法よりも, その都度治療対象臓器を 確認して位置決めを行うことが可能となることから， 位置決め精度の向上が期待され, 現在臨床的な検討を 進めている。しかしながら，本システムは照射室のス ペース等の問題から，CTが陽子線照射装置の横に隣 接しているため, 共通ベッドを回転させ，レール上を 手動で移動させる構造となって扔り, 移動距離が長 く, 複雑である。陽子線治療における位置再現性は, 病巣への最大限の線量を投与し, かつ周囲の重要藏器 への副作用を低減するために，大変重要な要素であ 
る.そのために共通ベッド等の精度管理を, 頻繁かつ 厳密に行う必要がある。

当センターに扔ける位置決めは, CTシミュレータ で決定された移動量を共通ベッドへ反映し，そのまま 照射位置でのアイソセンタとしている。ここで, CT 位置レーザ(以下CTポート)でマーキングされた位置 を，照射位置のレーザと合わせた方が，位置のずれは 少ないのではないか，という反論が考えられる，通 常, CTポートを参照したマーキングは，人的にペン 等を用いて行われる。この時のCTポートに対するマ 一キング精度は，マーキングする人物の経験と感覚, 呼吸による移動や非剛体なものへのマーキングの困難 さ，CTポートのレーザのサイズ，およびマーキング に使用されるペン等のサイズに依存していると考え る，また，照射位置レーザに対する，マーキング位置 の位置合わせ精度は，位置を確認する人物の経験と感 覚，レーザのサイズ，拉よびマーキングに使用される ペン等のサイズに依存すると考える. そのため, マー キングされた位置は，CTシミュレータで決定された 位置を，正確に反映されているとは言い難い，また， マーキング精度, および照射位置での位置合わせ精度 は, 時系列的観点から, CTシミュレータで決定され た位置に対してゆらぐ可能性は否定できない.

今回，本システムのレーザを使用せずに，検証ツー ル内のピアノ線を使用して，CTスキャンから照射位 置までの機械的位置精度を検証した結果, $1 \mathrm{~mm}$ 以内で なおかつ，その精度は既知である。そのため，マーキ ング，捛よびそれを利用した位置合わせに起因する， ずれの不確定要素を排除でき, 再現性も向上すると考 える。

現在までに報告されている，linacにお拈る，CT-共 通ベッドを使用したシステムの位置再現性は，いずれ も $1 \mathrm{~mm}$ 以内である2, 3). 当センターにおいても, レー ザおよびDRを用いて検証した結果，CTシミュレータ で指定したアイソセンタと照射位置でのアイソセンタ との誤差は $1 \mathrm{~mm}$ 以内であった。ただし，位置再現性 に使用された方法は，それぞれの施設間で異なってい るのが現状であり，IMRTや粒子線治療など高精度な 位置決めのQA (quality assurance)を行うためには，一
定の標準的な検証方法を策定する必要がある.

当センターで使用されているCTシミュレータシス テムは，CTから得られた画像ピクセルサイズを， 512 $\times 512$ から $384 \times 384$ へ変更している。このことは， 1 ピクセルあたりのサイズが，必然的に大きくなり，か つ補間による䛊差を生じさせる可能性が否定できな い。また，CTシミュレータ上で，目視による病巣中 心を決定する方法は，経験を必要とし，客観性にそし い，そのため, 現存のCTシミュレータに代わる, 自 動位置マッチングアルゴリズムを組み合わせた，新し い位置決めシステムを実現したいと考えている.

ヘリカルスキャン方式で，Z軸が約 $0.5 \mathrm{~mm}$ のずれを 確認した。これはコンベンショナルスキャンとへリカ ルスキャンとのスキャン収集アルゴリズム抢よび，画 像再構成アルゴリズムの違いによるものと考えられ， 正確な位置決めには, コンベンショナルスキャンが望 ましいと思われる。

最後に，当初中性子線等によるCTへの障害が懸念 されたが, 設置後 1 年 8 カ月を経過した現在, CTの 故障は経験していない.

\section{5. 結 語}

陽子線がん治療施設としては，初めてCTとCT-治療 共通ベッドを用いる，患者位置決めシステムを設置し た．機械的な位置のずれはX，Y，Z軸方向で，いずれ も $1 \mathrm{~mm}$ 以内であった，従来のX線透視装置を用いる位 置決め法よりも, 簡便かつ三次元的に高精度で, 再現 性の良好な位置決めが可能であることが示唆された。 今後, 患者の拘束時間をより短縮し, かつ精度を向上 できるような自動位置決め支援システムなどの開発を 予定している。

\section{謝 辞}

若狭湾エネルギー研究センター粒子線医療研究室の 福田茂一博士, 久米 恭博士に感謝いたします。

な扮，本論文の要旨は，第59回日本放射線技術学会 総合学術大会 (2003.4, 横浜)において発表した. 


\section{参考文献}

1) Uematsu M, Fukui $T$, Shioda A, et al.: A dual computed tomography linear accelerator unit for stereotatic radiation therapy: a new approach without cranially fixated stereotatic frames. International Journal of Radiation Oncology, Biology, Physics, 35 (3), 587-592, (1996).

2) Nishijima A, Nishimoto $H$, Fukuda $E$, et al.: Accurate radiation treatment system with a single couch, a ct simulation system and a linac. International Journal of Radiation Oncology, Biology, Physics, 48 (3), 343, (2000).

3) Kuriyama K, Onishi H, Sano N, et al.: A new irradiation unit constructed of self-moving gantry-ct and linac. International Journal of Radiation Oncology, Biology, Physics, 55 (2), 428$435,(2003)$.

Fig. 1 (a)CT-治療共通ベッドの外観と機構図

上方から見下ろした図を示す。

b(1)CTシミュレータを用いて，患者位置を決定.

b (2)CTから照射位置へ共通ベッドを移動.

b (3) 共通ベッドを照射位置へ固定.

Fig. 2 患者固定具支持台

Fig. 3 位置決め装置のずれ検証に使用した，検証ツールの外観

Fig. 4 患者を基準とした座標空間系

Table 1 各負荷における，CTレーザと照射位置レーザとのずれ量(頭方向から挿入)

Table 2 各負荷における, CTレーザと照射位置レーザとのずれ量(足方向から挿入)

Table $367 \mathrm{~kg}$ 人体における，CTレーザと照射位置レーザとのずれ量

Table 4 73.5kg負荷時における, CTレーザと照射位置DR十字ピアノ線とのずれ量 